\title{
Conceptualizing the Role of Leadership, Community Support, and Entrepreneurship Skill in the Performance of Community- Based Rural Homestay (CBRH) Programme in Malaysia
}

\author{
Kalsom Kayat ${ }^{\mathrm{a} *}$, Nur Farrah Ain Zainuddin ${ }^{\mathrm{a}}$, Razamin Ramli ${ }^{\mathrm{b}}$, Maznah Mat \\ Kasim $^{\mathrm{b}}$ \\ *Corresponding author: Kalsom Kayat, kayat932@uum.edu.my
}

${ }^{a}$ School of Tourism, Hospitality and Environmental Management, Universiti Utara Malaysia, 06010 Sintok, Kedah, Malaysia, ${ }^{b}$ School of Quantitative Sciences, Universiti Utara Malaysia, 06010 Sintok, Kedah, Malaysia

\begin{abstract}
http://dx.doi.org/10.15405/epsbs.2016.08.80

In Malaysia, $\mathrm{CBRH}$ is promoted by the government as a means to develop rural communities through their engagement in tourism small businesses. Both financial and non-financial supports have been provided by different government agencies to enable the program management and operators to serve quality services to the visitors and eventually to sustain their performance. This paper presents a conceptual analysis on variables that may influence CBRH's performance. Specifically, it explores the influential roles that can be potentially played by the selected determinants namely leadership, community support, and entrepreneurship skill.
\end{abstract}

CC 2016 Published by Future Academy www.FutureAcademy.org.uk

Keywords: Community-based tourism; community-based project; rural tourism; rural development.

\section{Introduction}

The Ministry of Tourism and Culture began to promote the community-based rural homestay (CBRH) program in year 1995, which essentially is a community-based tourism product that offers refreshing rural environment and local community lifestyle experience to the visitors. Besides offering visitors with an alternative tourism experience, this program is also aimed to generate tourism income to rural population as participating communities are encouraged to operate accommodation within their dwellings to the visitors as well as to offer other income generating activities to their guests 
(Mapjabil et al. 2015). These activities are said to benefit the communities both collectively and individually (Novelli and Gebhardt, 2007; Simpson, 20017; Goodwin and Santilli, 2009).

It has been remarked that $\mathrm{CBRH}$, which fits the description of a community-based tourism (CBT) initiative, preserves the local culture and conserves the nature (Nair and Hamzah, 2015). Known as an economic booster, $\mathrm{CBRH}$ contributes significantly to the development of local communities especially in the rural areas (Mapjabil et al., 2015; Ramli et al., 2015). Income, social and physical development are the main motivation factors for the homestay operators to participate in the program (Abdul Razzaq, Hadi, and Mustafa, 2011).

In the 9th Malaysia Plan, a sum of RM40 million was allocated by the ministry to upgrade the infrastructures and facilities of homestay program (Ramli et al., 2015). Moreover, series of training were given to the homestay operators prior to their participation in the homestay program as to prepare them as hosts. The success of this program is reflected by its ability to self-sustain thus generate income to the community, amidst its independence from stipulations and control of any aid agencies or government bodies (Mizal, Fabeil, and Pazim, 2014). Regardless of many success stories about the homestay program in earlier studies, there are still homestay operators who withdrew from the program as they fail to sustain (Pusiran and Xiao, 2013). The government needs to know whether a CBRH program can and cannot perform in order for them to strategize the whole CBRH program. This paper attempts to conceptualize our understanding of the program's success determinants as an early effort to come up with informed decisions that may assist the government.

\section{Literature Review}

\subsection{Studies on Community-based Tourism Initiatives' Performance}

The various challenges faced by community-based tourism initiatives across the globe has been documented (Hamzah and Mohamad, 2012). Weaknesses in financial and organizational resources have definite effects on the quantitative and qualitative performance of the homestay program. Previous studies on CBT have mostly focus on the success of the existing CBT, including the Malaysian homestay program, without exploring in depth the reason for the success. Understanding determinants to the homestay's performance will help in strategizing the program as an effective tool to generate income and create employment opportunities to the communities through tourism.

$\mathrm{Hu}$ et al. evaluate the performance of homestay program in Taiwan using Analytic Network Process (ANP) (Hu, Wang and Wang, 2012). The researchers gathered the weights of the factors involved to acquire the performance guided by fuzzy theory. Their findings showed both homestay operators and visitors in their study weighed four criteria namely physical attraction of accommodation, service quality, homestay operation and homestay management as very important. Earlier, a study by Maliao et al. (2009) examine seven factors; participation, influence, control, access, income, conflict management, and compliance on the performance of community-based coastal resource management. It showed that the programs are effective in engaging the local community in managing their local resources. However, they are still in doubt on the capacity of the program to improve their living in the future. The present authors feel that a priori criteria should also be looked 
http://dx.doi.org/10.15405/epsbs.2016.08.80

eISSN: 2357-1330 / Corresponding Author: Kalsom Kayat

Selection and peer-review under responsibility of the Organizing Committee of the conference

into; the community needs to have several criteria before they can excel in the areas found by both of the studies.

Using an arithmetic average method to evaluate critical success factors of a homestay program, it has been found that a community's ability and capacity to run the program has the highest average rating, followed by benefits to the community, conservation of community resource, and leadership (Daud, 2015). Capacity and ability are highly influential and they are indeed important success criteria tor the homestay, thus need to be explored further.

In addition, it is suggested that in order to improve the business performance of homestays in this country, homestay operators should focus on improving their ability and capacity and focus on enhancing their leadership skills (Ramli et al., 2015). Thus far, studies on the performance of homestay program are still limited and more studies need to be undertaken to explore other factors that may determine this success.

\subsection{Leadership's Potential Role}

The CBRH is essentially a community program in which community participation as well as sound leadership play important roles. Poor leadership may cause the program to be ineffective in generating income and other benefits to the community. Indeed, leadership has been discussed in the literature an important element in a homestay program (see for example Pusiran et al., 2013; Abdul Razzaq, Hadi, and Mustafa, 2011; Mizal, Fabeil, and Pazim, 2014; Hamzah and Mohamad, 2012; and Kontogeorgopoulos, Churyen, and Duangsaeng, 2014). According to Pusiran and Xiao (2013), the relationship between leadership and the unity of the community enhance the sense of ownership and pride among them, thus motivate them to work together toward the success of such programs. They added that a competent community leadership should be sustained as it has a close relation with the community empowerment. Mizal et al. (2014) also found that the community entrepreneurship excellence depends heavily on the local champion that lead a community-based tourism (CBT) initiative. As an example, dynamic leadership is one of the important element found to have made Miso Walai Homestay to become a successful community-based ecotourism initiative (Hamzah and Mohamad, 2012).

A community project needs a leader as the community may not be ready for the intended changes or development. Thus, the leader or local champion for a successful CBT program such as the CBRH must be able to fulfil multiple roles competently and must possess the skill to communicate the communal benefits of the CBT, the plan to avoid possible disruptions to their relationships with external actors, as well as to lead resistance against the temptation to continue expanding the tourism beyond the community's carrying capacity (Kontogeorgopoulos, Churyen, and Duangsaeng, 2014).

\subsection{The Critical Role of Community Support}

Almost all community-based projects are meant to benefit the members of the community. Thus, it requires support from its members. CBRH program must be supported by the community itself for it to thrive and sustain. Community support includes participation by the community in every stage of the program as well as their commitment in making sure that the program is implemented successfully. 
The support of the local population is essential for the development, successful operation, and sustainability of tourism initiative in their community (Jurowski, Uysal, and Williams, 1997). In addition to leadership, community support is another determinant factor for CBRH program success.

Several studies have shown that community involvement is very crucial in the homestay program (Pusiran et al., 2013; Ibrahim and Abdul Razzaq, 2010). The community must be given the ability and capability to be involved in a community-based program. Increasing the capacity of the community in itself is benefit from such program as the community members will experience 'development' as their ability and capability are enhanced (Hamzah and Mohamad, 2012). Community support will lead to interaction between hosts and guests; these interactions as well as experience from the interactions will in turn contribute in strengthening the participating members of the community. Only when this take place will the benefits of the community based tourism development be materialized (Abdul Razzaq, Hadi and Mustafa, 2011).

The CBRH program is intended to be a winning tourism product to lure tourists and a tool for the development of rural areas and its people. However, its implementation requires commitment and understanding among the communities especially if it is to survive without aids from agencies (Ghasemi and Hamzah, 2011). Active involvement and participation of residents in the tourism development process seem to be prerequisites for achieving the goal of sustainability and thereby improving the overall welfare in the community (Ertuna and Kirbas, 2012). In addition, community capacity building that focuses on increasing local participation, knowledge and skill of local community, as well as to instil leadership, strengthen community structure, establishing sense of community as well as external partnership are the critical success indicators for the homestay program development in Malaysia (Abdul Razzaq, Hadi and Mustafa, 2011).

\subsection{Entrepreneurial Knowledge and Skill}

The next variable is very much related to first two discussed earlier. In order for the CBRH program to be carried out successfully, local members of the community who are involved as the homestay operators or those who provide other services offered to the visitors must possess entrepreneurship skills. The CBRH program needs to be approached not merely as a community project, but also as a business. In CBRH program, residents work together to 'build' the business for the program to be sustained (Sharif and Tuan Lonik, 2014).

The entrepreneurial aspect of a community-based project is needed especially because the project involves providing quality service as a way to secure competitive advantage and to sustain. This will then make the project become a part of an important tourism development policy (Mapjabil et al., 2015). As the nature of homestay program is community based, it creates opportunity to nurture thriving rural entrepreneurship among the participating community members (Nair and Hamzah, 2015). Those involved in CBRH program must view at their activities as entrepreneurs. This is crucial order to develop the economic potential and to determine the direction of a development in rural areas (Sharif and Tuan Lonik, 2014).

Entrepreneurship is indeed a main criterion to boost economics in rural areas. It is usually developed to further enhance the economic potential of rural areas. Emphasis on the entrepreneurial 
knowledge and skill should be given to allow the participating members of the community, the entrepreneurs and the agencies concerned to cooperate and work together to strengthen and further develop rural entrepreneurship (Sharif and Tuan Lonik, 2014).

\section{Conclusion}

This paper began with an explanation about the importance in understanding the determinants of CBRH program's performance. Studies on the performance of homestay program are crucial to the stakeholders as to monitor the effectiveness of $\mathrm{CBRH}$ in rural community development. There are many factors that may influence the performance of; this paper discusses three of the probable factors, namely leadership, community support and entrepreneurs skills (Che Ismail, Mapjabil, and Masron, 2014). Further studies using primary data and a tested instrument are recommended.

\section{References}

Abdul Razzaq, A.R., Hadi, M.Y., and Mustafa, M.Z. (2011). Local Community Participation in Homestay Program Development in Malaysia. Journal of Modern Accounting and Audit, 7(12), 1418-1429.

Daud, S.M., Ramli, R., Kasim, M.M., Kayat, K., and Razak, R.A. (2015). The use of arithmetic average method in identifying critical success criteria for Homestay Programmes. In Proceedings of the 2nd Innovation and Analytics Conference \& Exhibition IACE 2015

Ertuna, B. and Kirbas, G. (2012). Local community involvement in rural tourism development: The case of Kastamonu, Turkey. Revist a de turismo y patrimonio cultural, 10(2), 17-24.

Ghasemi, M. and Hamzah, A. (2011). An Evaluation of the Role and Performance of NGOs in Community- Based Ecotourism at Ulu Geroh, Gopeng, Malaysia, Monograph. No. 9, 9(9).

Goodwin, $H$. and Santilli, $R$. (2009). Community-based tourism : A success? ICRT Occasional Paper 11, 11(1), 137.

Hamzah, A. and Mohamad, N.O.R.H. (2012). Critical Success Factors of Community Based Ecotourism: Case Study of Miso Walai Homestay, Kinabatangan, Sabah, The Malaysian Forester, 75(1), 29-4.

Hu, Y.C., Wang, J.H. and Wang, R.Y. (2012). Evaluating the Performance of Taiwan Homestay Using Analytic Network Process, Mathematic Problem Engineering,1, 1-2.

Ibrahim, Y. and Abdul Razzaq, A. R. (2010). Homestay Program and Rural Community Development in Malaysia, Journal of Ritsumeikan Social Sciences and Humanities, 2, 7-24.

Jurowski, C., Uysal, M. and Williams, D.R. (1997). A theoretical analysis of host community resident reactions to tourism, Journal of Travel Research, 36(2), 3-11.

Kontogeorgopoulos, N., Churyen, A. and Duangsaeng, V. (2014). Success factors in community-based tourism in Thailand: The role of luck, external support, and local leadership, Tourism Planning and Development, 11(1), 106-124.

Maliao, R.J., Pomeroy, R.S. and Turingan, R.G. (2009). Performance of community-based coastal resource management (CBCRM) programs in the Philippines: A meta-analysis, Marine Policy, 33 (5), 818-825.

Mapjabil, J., Ismail, S.C., Rahman, B.A., Masron, T. and Ismail, R. (2015). Homestays - Community programme or alternative accommodation? A re-evaluation of concept and execution, Geography Online Malaysia Journal of Society and Space, 12 (12), 1-8.

Mizal, K., Fabeil, N.F. and Pazim, K.H. (2014). Financial sustainability of Community-based tourism (CBT): The case of tourism cooperative limited (KOPEL BERHAD), International Journal of Research in Management and Business Studies, 2(1), 23-32.

Nair, V. and Hamzah, A. (2015). Successful community-based tourism approaches for rural destinations: The Asia Pacific experience, Worldwide Hospitality and Tourism Themes, 7(5), 429-439.

Novelli, M. and Gebhardt, K. (2007). Community Based Tourism in Namibia: 'Reality Show' or 'Window Dressing'? Current Issues in Tourism, 10 (5), 443-479.

Pusiran, A. K. and Xiao, H. (2013). Challenges and community development: A case study of Homestay in Malaysia, Asian Social Science, 9(5), 1-17.

Ramli, R., Kasim, M. M., Kayat, K. and Razak, R. A. (2015). Ranking the criteria for sustainability of communitybased rural homestay programmes from the perspective of the operators. In Proceedings of the 2nd Innovation and Analytics Conference \& Exhibition IACE 2015.

Sharif, N.M. and Tuan Lonik, K.A. (2014). Entrepreneurship as a catalyst for rural tourism development. SHS Web of Conferences, 12, 01087.

Simpson, M. C. (2007). Community benefit tourism initiatives - A conceptual oxymoron? Tourism Management, $29(1), 1-18$ 